\title{
The effects of entrepreneurial orientation and organizational learning on marketing capability in supply chain management
}

\author{
Peridawaty $^{\mathrm{a}^{*}}$, Rita Yuanita Toendan ${ }^{\mathrm{a}}$ and Ina Karuehni Wenthe ${ }^{\mathrm{a}}$
}

${ }^{a}$ Lecturer, Faculty of Economic and Business, Palangka Raya University, Central Kalimantan, Indonesia

\begin{tabular}{l}
\hline C H R O N I C L E \\
\hline Article history: \\
Received October 2, 2020 \\
Received in revised format \\
November, 10, 2020 \\
Accepted December 202020 \\
Available online \\
December 242020 \\
\hline Keywords: \\
Entrepreneurial Orientation \\
Organizational Learning \\
Marketing Capability \\
Customer Satisfaction
\end{tabular}

1. Introduction

Supply chain management is a broad and complex business that depends on every partner from suppliers to producers and to consumers in order to run well (Ab Talib et al., 2015). This strategy is carried out with supply chain-based management to maximize customer value and gain a competitive advantage in the market (Al-Aomar \& Hussain, 2018). To achieve this, competitive advantage requires customer satisfaction which is carried out with various efforts, both business strategy and special software (Aparicio et al., 2017). Business and changes in the business environment really require expertise to stay focused on customer needs in realizing customer satisfaction (Cacciolatti \& Lee, 2016). Products that are environmentally friendly and provide good quality products for long-term use in the present have become the choice of consumers in times of pandemic that prioritize health. The eco-friendly material business unit can continue to survive and maintain customer loyalty, even in terms of high prices. Online marketing methods are positive changes that can increase consumer satisfaction, so that business methods with SCM require proactive, innovative, risk taking and organizational learning (Abu Seman et al., 2019). The form in the previous empirical study states that Supply Chain Management is a series of activities needed to plan, control, and run product flows (Berghman et al., 2012). This includes the process of obtaining raw materials, the production process, and the distribution of products to end consumers in the most efficient and cost-effective manner (AlHazmi, 2020). In Indonesia, people are now familiar with the online marketing system and of course this makes it easy for small and medium enterprises to develop businesses by marketing online (Kristinae et al., 2019). The entrepreneurial orientation capability business method that encourages marketing capabilities is not significant in previous research, because

* Corresponding author

E-mail address: peridawatyFEB1@gmail.com (Peridawaty)

C 2021 by the authors; licensee Growing Science. doi: $10.5267 /$ j.uscm.2020.12.005 
it is unable to adjust the business environment by making a business strategy in a marketing system that suits consumer needs (Qureshi et al., 2017). Of course, it also relates to studying the ability of a business unit to determine customer needs to get customer satisfaction. Resources Based View (RBV) theory states that a business based on resources as a driving force and determinant of business sustainability must be able to change business methods by taking into account the business environment (Barney, 2001). Therefore, this study is based on the RBV theory and customer satisfaction emphasizes changes in business methods with SCM strategies in marketing capabilities (Khaddam et al., 2020). The management of an organization's business management that has a current brand image is also affected due to a decrease in business income, so that organizations need system changes in reaching customers by implementing customer satisfaction (Soltani et al., 2014). Change must start from the organization, such as being active in looking for opportunities, innovative in creating ideas and the ability to calculate risks as indicators of entrepreneurial orientation (Cenamor et al., 2019). But in previous studies stated that the business unit with EO is not the main basis in increasing the business becomes a research gap. Entrepreneurial-oriented consumer satisfaction in several studies shows that it can be significantly applied as a business strategy to manage business management effectively and efficiently. Business units that are able to manage management can have a significant impact on customer satisfaction despite changes in business with changing needs (Al-Dhaafri et al., 2016). The measure of business success can survive in conditions of significant business changes to customer satisfaction that can be managed effectively and efficiently based on consumer needs with online promotions and online services.

This pandemic period is an opportunity for the body shop products in Central and South Kalimantan, because these products are made from plants that do not damage the skin / without side effects. The products offered before the pandemic had a brand image of safe and halal products and prioritized skin health even though the price was more expensive than chemicalbased body care products (Kristinae et al., 2020; Hong \& Guo, 2019). The current economic challenges of society and the sluggishness in purchasing products are problems of the body shop products that can be sustainable, for that the marketing capability variable is adopted with a strategy of implementing SCM based on RBV theory, in order to increase customer satisfaction. Business units that are able to synergize with environmental changes such as entrepreneurial orientation, organizational learning and marketing capabilities significantly positively increase customer satisfaction (Berghman et al., 2012). The phenomenon of research in gaining profits is like before, such as in The Body Shop products, based on interviews that focus on products that ensure the health of skin and hair in Central and South Kalimantan, there is a decrease in income due to a decrease in people's purchase intention due to high product prices, even though the product quality is very good. The SCM management strategy in product marketing capabilities in the marketing sector is to get opportunities in environmental conditions that prioritize products that can be trusted in terms of health based on product raw materials, synergize with encouragement of entrepreneurial orientation expertise, organizational learning to improve consumer satisfaction. The research implication is to increase customer satisfaction for business sustainability by being proactive, innovative, risk taking, organizational learning, encouraging the marketing capabilities needed by the market and needed in building relationships with customers.

\section{Literature Review}

Supply chain management is a strategy and system that must be controlled by an organization, involving so many processes, from production preparation to meeting consumer needs. As planning includes several activities that are involved in the planning stage, from forecasting consumer demand, purchasing planning, and production planning, to preparing labor and transportation, it becomes the organization's concern in managing and taking policies that will have a good impact on business capabilities through customer satisfaction. (Khaddam et al., 2020). Predictions of consumer satisfaction starting from consumer demand are carried out so that sellers can find out the types and quantities of products that must be prepared during a certain period of time. This is important to ensure that the products to be produced and sold are in accordance with consumer demand with entrepreneurial orientation and marketing capabilities (Kristinae, 2019).

\subsection{Customer Satisfaction on environmentally friendly products}

Customer Satisfaction is a level where the needs, wants and expectations of customers can be fulfilled, which will result in repeat purchases or continued loyalty (Adam et al., 2020). How much customer satisfaction is with a company or product, really depends on the method of service and product distribution. In general, there are 3 (three) stages of customer satisfaction, namely: satisfaction because basic customer needs are met, satisfaction because it meets customer expectations in a way that makes them come back again, and satisfaction because the company does more than what the customer expects. This includes the product quality of all the components that make up the product so that the product has added value. In the eco-friendly product business, the relationship between the value and price of a product is determined by the difference between the value received by the customer and the price paid by the customer for a product produced and good service so that the customer feels the benefit of the product (Kristinae et al., 2020). The form of business that produces products must be able to manage resources effectively and efficiently in RBV theory, so that the components of the business strategy of a product can produce a benefit from the company called reliable if it is able to produce products based on customer satisfaction. Customer satisfaction with environmentally friendly products shows basic facts in terms of product raw materials for consumers who are aware of the importance of skin health. The business unit as a service provider, or a change in consumer reaction to consumers, must be able to properly inform products regarding product differences and product benefits to customers, so that expectations and expectations do not compare much in an effort to increase customer satisfaction (El-Adly et al., 2016). Customer satisfaction is a customer evaluation of a product or service in terms of whether 
that product or service meets customer needs and expectations (Basari et al., 2020). Every organization that is customeroriented needs to provide opportunities and easy and convenient access for its customers to submit their suggestions, criticisms and complaints. Commonly used media include suggestion boxes, comment cards, toll-free dedicated telephone lines, websites and others. This is business method can provide valuable ideas or input to the company. CS is so important applied with supply chain management methods, so that resources can be managed effectively and efficiently. Because seeing the types and quantities of goods that must be purchased through demand forecasts, obtaining these goods is a method of selling the acquisition of goods at the best price, in the right amount, and at the right time, so that the company benefits from customer satisfaction (Kuo et al., 2019).

\subsection{Entrepreneurial Oriention (EO) encourages Marketing Capabilities (MC) to increase Customer Satisfaction (CS)}

Entrepreneurial orientation and customer satisfaction are closely related to the strategy formulation process in RBV theory, which will provide the basis for decision making and business implementation of the organization. Entrepreneurial orientation plays an important role in increasing customer satisfaction. Entrepreneurial orientation becomes an acceptable meaning for proactive, innovative and risk taking activities by business units so that resources are right on target. Entrepreneurial orientation refers to processes, practices, and decision-making that encourage new inputs and has three aspects of entrepreneurship, namely taking risks, acting proactively and always being innovative (Qureshi et al., 2017). Daring to take risks is an entrepreneurial attitude that involves their willingness to tie up resources so that they are managed optimally (Barney, 1991) and dare to face challenges by exploiting or engaging in business strategies where the possible results are full of uncertainty (Kristinae et al., 2019). Proactive reflects the willingness of entrepreneurs to dominate competitors through a combination and aggressive and proactive movements, such as introducing marketing products or services above competition and activities to anticipate future demands to create change and achieve customer satisfaction. Innovative refers to an entrepreneurial attitude to be involved creatively in the process of experimenting with new ideas that make it possible to produce new production methods so as to produce new products or services, both for the current market and for new markets based on consumer satisfaction (Basari et al., 2020). The character of entrepreneurship and the not yet optimal managerial role in managing a business in a rapidly changing business environment greatly affects customer satisfaction. To be able to develop a business, a management system is needed that can provide satisfaction to consumers, such as the sales system in the marketing capability program (Lekmat et al., 2018). In this case, EO encourages marketing capabilities, namely how activities on capabilities are carried out proactively, innovatively and risk taking related to customer satisfaction. Nahan et al. (2019) defines entrepreneurship orientation as a resource-based strategy to get company benefits by competing more effectively in the market place maximally to reach as many consumers as possible. Meanwhile, according to Kristinae et al. (2020), that there is a significant relationship between entrepreneurial orientation, encouraging marketing capabilities, so that consumers feel easy to obtain information and transactions. Entrepreneurial orientation refers to processes, practices, and decision making that lead to new inputs and has three aspects of entrepreneurship, namely taking risks, acting proactively and always being innovative (Lumpkin \& Dess, 1996). A high entrepreneurial orientation is closely related to the main driver of profit so that entrepreneurs have the opportunity to take advantage and the emergence of these opportunities, which in turn has a positive effect on consumer satisfaction (Cuevas-Vargaz et al., 2019). The results felt by customers on product quality will be capable of repeated purchases. Customers who tend to be satisfied will be loyal to the product longer and have an impact on increasing customer satisfaction. Based on product quality specifications and standard health protocols during the COVID-19 pandemic, it is necessary to do this with antecedent knowledge of related parties. Strategies in business units are generally determined by the relationship between business actors and consumers from reliable product quality that can meet customer needs (Kristinae et al., 2019). Business actors who are able to increase consumer satisfaction from the knowledge of EO-based business units in reliable activities or media apply sustainable business methods to encourage marketing capabilities. Based on previous research and theory, the hypothesis proposed in this study are:

\section{$\mathrm{H}_{1}$ : Entrepreneurial orientation has a significant positive effect on Marketing Capability.}

\subsection{Organizational Learning (OL) encourages Marketing Capabilities (MC) to Customer Satisfaction (CS)}

Organizational learning is defined as an organization that has the ability to continuously improve systems / methods to increase customer satisfaction. Because business actors who have knowledge, learning abilities and individual commitment and competence and are able to learn and share knowledge can face changes as a result of better consumer satisfaction measures (Abu Seman et al., 2019). Organizational learning is a method that describes an organization as an integrated and always changing system, because individual members of the organization experience a learning process based on customer satisfaction. The individual learning process occurs when organizational members experience a process of understanding new concepts (know-why), which is followed by increased ability and experience to realize these concepts (know-how), resulting in changes or increases in organizational added value (Andreou et al., 2019). Organizational learning in the theory unit RBV is a company that realizes the importance of training and organizational development related to continuous efforts so that resources move well and are willing to take appropriate action in increasing customer satisfaction (Christa et al., 2020). Consumer satisfaction can provide a good explanation of the success of a business unit as a measure of product success and is a concept used to describe the types that affect customer satisfaction (Sudari et al., 2019). One of the efforts contained in organizational learning refers to activities such as supportive leaders, culture of continuous improvement, defined learning structures and intuitive knowledge processes. Thus, the company has an effort to become a learning organization in the formation by taking into account the factors of culture, strategy, structure and organizational environment 
to synergize with marketing capabilities. It is further argued that there are characteristics that an organization must have in order to succeed in becoming a learning organization, namely: 1. There are opportunities to learn for all components in the organization, not only formally but also manifest in daily activities. 2 . There is a design of organizational structure and culture that ensures, stimulates, and allows all components in the organization to learn, ask about existing management practices, experiment, and contribute with new, fresher ideas (Migdadi et al., 2019).

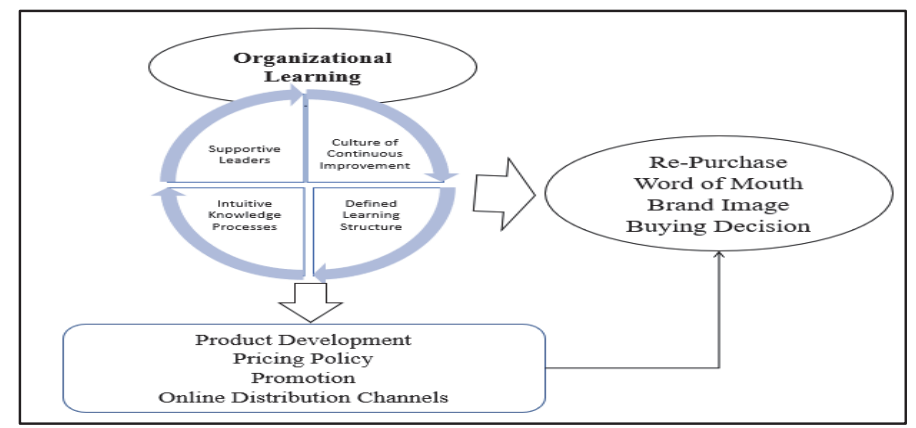

Fig. 1. The Process of Implementing Organizational Learning (source: mindmapping by the author)

The OL process in the picture above is mapped by the author to maximize the organization in managing resources with the SCM method such as procurement of goods that has several stages, namely submitting purchases, purchasing approvals, and ordering to suppliers (Abdirad et al., 2020). So that to make the necessary policies resource-based organizational learning that is responsible for overseeing and determining goods to order to increase customer satisfaction. OL will become easier and simpler with the help of a management system for product purchases, so that OL is the main point in driving marketing capabilities. In RBV theory, the activity forms of marketing capabilities, so that resources can be managed effectively and efficiently, including indicators: new product development, online services and online promotion, software can make requests for quotes, purchase orders, approvals, and umbrella contracts faster (Migdadi \& Mahmoud, 2019). Good procurement software even provides a supplier portal to speed up the ordering process. Organizational learning is needed to encourage marketing capabilities to increase customer satisfaction. Based on theory and empirical study, the proposed investigations are:

\section{$\mathrm{H}_{2}$ : Organizational Learning significantly increases Marketing Capability.}

\subsection{Organizational Learning (OL) increases Customer Satisfaction (CS)}

Organizational learning in companies that have products must be able to continuously learn how to create business methods, promote products, and marketing systems that will be formed if individual members of the company are able to continue to learn to make themselves business supervisors based on consumer needs (Altinay et al., 2019). OL formed is characterized by the growth of individual company skills, skills to understand the strengths and weaknesses of their intellectual, emotional and social competences, as well as the skills to revise their personal vision, and then the skills to build working conditions in accordance with the circumstances of their organization. Organizational Learning requires a vision agreed upon by all members of the organization / company as a trigger for enthusiasm and commitment to always be together, thus fostering motivation to learn and continue to learn to improve competence (Anonymous, 2016). Organizations will find it difficult to see the various realities that exist, if members of the organization are unable to formulate appropriate assumptions and values to be used as a basis for thinking and for viewing various organizational problems (Antunes \& Pinheiro, 2020). The skills to find common principles and values, as well as the growth of the business unit's ability to foster a spirit and commitment to togetherness, are the OLs needed to drive customer satisfaction. Team learning will be effective if the ability to act as a prerequisite for creating added value for the company as a business method, because the ability to act according to a common plan is often hampered by the communication system and coordinates properly with other parties (Agarwal, 2019). There is a relationship between various internal or external factors that affect the existence of an organization, such as skills for integrative thinking, thinking skills, and skills to build adaptive organizations that are needed to build customer satisfaction. Customer-centered organizations provide ample opportunities for customers to submit suggestions and complaints. This information can provide bright ideas for the company and allow it to react responsively and quickly to solve problems that arise (Akinci \& Sadler, 2019). The dynamics of the business world that are increasingly moving fast and changes in consumer behavior are increasingly unpredictable, requiring companies to start shifting attention to customer satisfaction measures by managing resources effectively and efficiently in RBV theory, which states that the SCM method is the key to implementing management processes. Thus, the company not only pursues business profit but is also able to give more priority to customer satisfaction. Customer satisfaction needs to get more priority considering the benefits that can be obtained by companies that have products, grow and develop based on consumer needs (Kuo \& Nakhata, 2019). A high level of customer satisfaction increases customer loyalty, reduces the turnover of consumers who turn to competitors, and is able to improve the company's reputation. Based on previous research and research theory, the hypothesis proposed in this study is as follows,

\section{$\mathrm{H}_{3}$ : Organizational Learning has a significant positive effect on increasing consumer satisfaction.}


Dynamic Marketing Capability is a marketing system that focuses on the ability of business actors to introduce products, develop products, price alignment, communication skills (promotions), provide services in sales, distribute products to increase consumer satisfaction (Kristinae et al., 2020). In RBV theory, marketing capability becomes a program to deal with the uncertainty problem of consumer satisfaction, so a business method with a supply chain approach is needed to share information along the supply chain, optimization of supply levels, team supply management, supply chain measurement, as well as building coordination and collaboration among partners. business. So that the process that allows companies to achieve low inventory costs and remains based on customer satisfaction (El-Adly \& Eid, 2016). Business units need to apply marketing capabilities that are managed with adequate knowledge and a marketing capability system to increase customer satisfaction with a supply chain management-based business strategy. SCM as a strategic coordination of the supply chain with the aim of integrating supply and demand management. supply chain management is a total system approach to delivering products to end consumers by using information technology to coordinate all elements of the supply chain from suppliers to retailers, then reaching the next level (Khaddam et al., 2020). The stronger the push for dynamic marketing capabilities as a business strategy, the better the marketing system is to be able to increase customer satisfaction. Companies that are able to implement antecedents of organizational learning will be able to encourage marketing capabilities based on consumer needs in order to increase customer satisfaction (Andrews, 2017). Based on previous theory and empirical studies, this study proposes the following hypothesis:

$\mathrm{H}_{4}$ : Marketing Capabilities significantly positively increase Customer Satisfaction.

\section{Research Methods}

This research was conducted in two provinces in Indonesia based on a survey of respondents who prefer environmentally friendly products as skin care "The Body Shop". This research is quantitative in nature with multiple regression analysis test with SPSS 23.0 program, and uses questionnaires to 100 consumers of the body shop products in Central Kalimantan and 100 consumers in South Kalimantan, Indonesia as respondents. The sample population is considered relevant if the results of the sample test as many as 30 in each study location are not biased (Christa et al., 2020). Consumers who are sampled are taken randomly and have the body shop customer card, so that the results can be trusted. Furthermore, this research builds models and hypotheses to interpret the results from the RBV theory and is supported by previous empirical studies having a research model framework as follows:

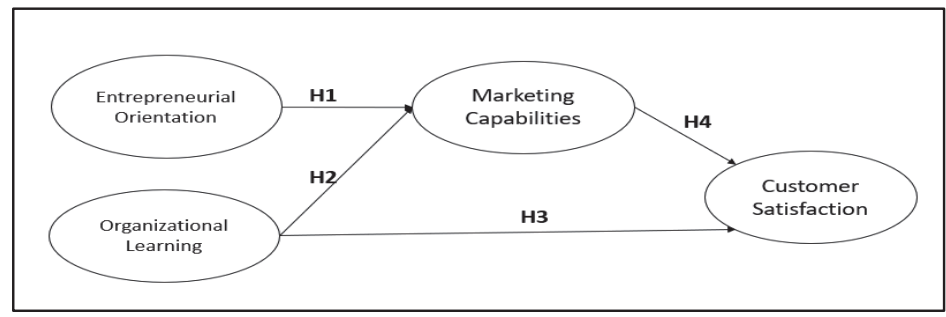

Fig 2. Research framework model

\section{Result of data analysis}

This study conducted an instrument test on a questionnaire in answering questionnaires made on an instrument with a Likert scale in answer options 1 (strongly disagree) to number 5 (strongly agree) (Christa \& Kristinae, 2020). The purpose of the initial testing of the instrument is so that the questionnaire items that reflect the indicators can be trusted as a result of the data analysis. Based on the answers to the questionnaire, then processed with the SPSS 24.0 program and tested the validity and reliability instruments beforehand. The results of the trial instrument of 30 respondents showed validity and reliable results, shown in Table 1.

Table 1

Validity test and reliable test

\begin{tabular}{lcccc} 
& EO & OL & MC & CS \\
\hline Pearson Correlation & $0.901^{* *}$ & $0.925^{* *}$ & $0.918^{* *}$ & 0.000 \\
Sig. (2-tailed) & 0.000 & 0.000 & 30 & 0.000 \\
N (trial instrument) & 30 & 0.913 & 30 & 0.906 \\
Cronbach's Alpha & 0.903 & 0.911 & 30 \\
\hline
\end{tabular}

Source: the author's data were analyzed by SPSS 23.0

This type of research data is primary data collected randomly in two different provincial locations and is a direct result of respondents regarding customer satisfaction obtained by applying health protocols as reliable information in this study. According to Nahan (2019) the results of research based on direct respondent data will be more subjective to the results of the research, to become a reference in making better changes to the company. The method of taking interviews to answer the questionnaire directly and analyzed by SPSS has multiple linear regression equations with the formulation: 
$\mathrm{Y}_{2}=\mathrm{a}($ constant $)+\mathrm{b}_{1} \mathrm{X}_{1}($ Entrepreneurial Orientation $)+\mathrm{b}_{2} \mathrm{X}_{2}($ Organizational Learning $)+\mathrm{b}_{1} \mathrm{Y}_{1}$ (Marketing Capability) + error

Information: $\mathrm{Y}_{2}=$ Customer Satisfaction and $b_{i}=$ regression coefficient

\section{Research Results}

\subsection{R-square test}

Based on the questionnaire from 200, namely body shop customers and the results of data analysis, it can be seen from Table 1 that the effect of X1, X2, Y1 on Y2 has a significant effect on adjusted R-Square, namely $62.5 \%$. These results state that the Entrepreneurial Orientation as X1, X2 Organizational Learning, Y1 Marketing Capability is very important to increase Y2 consumer satisfaction. The presentation results that show the importance and positive significance of each variable $\mathrm{X} 1, \mathrm{X} 2$, Y1 through the indicators can increase customer satisfaction by $62.5 \%$ and the remaining $37.5 \%$ other factors that are not examined in the research model.

Table 2

R-Square regression value

\begin{tabular}{lcccc}
\hline Model & $\mathrm{R}$ & R Square & Adjusted R Square & Std. Error of the Estimate \\
\hline 1 & $.712^{\mathrm{a}}$ & .698 & .625 & .323 \\
\hline a. & Predictors: (Constant), Entrepreneurial Orientation, Organizational Learning, Marketing Capabilities. Source: Processed data by author's &
\end{tabular}

The results of this R-Square test provide evidence that the better the company is in managing entrepreneurial orientationbased management, being able to apply awareness of the importance of organizational learning and the better the system on marketing capabilities, the better it will be in increasing customer satisfaction. Previous empirical studies stated that customer satisfaction is a strategy that should be carried out by product companies to maintain business revenue stability and business sustainability.

\section{2 t-statistic test (entrepreneurial orientation increases marketing capabilities)}

Further testing is carried out by using the $t$ test or analysis test partially in testing the relationship between variables that affect the dependent variable (Kristinae et al., 2020). Based on the data test to answer the hypothesis, it is carried out as an interpretation of the results that do not show the large influence of exogenous variables on endogenous. A significant and positive relationship indicates that the hypothesis is accepted, which means that it can meet the statistical requirements in such as the $t$ test, significance, beta standard coefficient and the f test on the results (Shahzadi et al., 2018).

Table 3

Statistical t-test (entrepreneurial orientation increases marketing capabilities)

\begin{tabular}{|c|c|c|c|c|c|c|}
\hline \multirow{4}{*}{1} & & \multicolumn{2}{|c|}{ Unstandardized Coefficients } & \multicolumn{3}{|c|}{ Standardized Coefficients } \\
\hline & Model & $\mathrm{B}$ & Std. Error & Beta & $\mathrm{t}$ & Sig. \\
\hline & (Constant) & .043 & .027 & & 1.130 & .000 \\
\hline & Entrepreneurial Orientation & .769 & .073 & .514 & 3.175 & .000 \\
\hline
\end{tabular}

a. Dependent Variable (Marketing Capabilities). Source: Processed data by author's

In the research results, it can be concluded that if the results show comparisons, if the t-count is greater than the t-table, the hypothesis can be accepted, meaning that there is a direct effect affecting the endogenous. Likewise, if the results of the significance probability are smaller than 0.05 , the hypothesis is accepted, meaning that there is a significant and positive influence of exogenous variables on endogenous variables. Based on the results in Table 3, it states that hypothesis 1 can be accepted because the t-test is $3.175 \geq 0.6757 \mathrm{t}$-table and the significance is $0.00 \leq 0.05$. Meanwhile, the result of standardized coefficients beta was 0.514 , which means that the entrepreneurial orientation had a significant positive effect of $51.4 \%$ on marketing capabilities.

\section{3 t-statistic test (organizational learning improves marketing capabilities)}

In this study, the OL variable in pushing MC from the direct effect test in driving the marketing system currently has to follow the changing environment of consumer demand to increase customer satisfaction from marketing capabilities. The better the company applies OL, the more it will be able to manage the management of the business pattern to be ready to face situations and situations even with a marketing system that suits consumer needs.

Table 4

t-statistical test (Organizational Learning on Marketing Capabilities)

\begin{tabular}{|c|c|c|c|c|c|c|}
\hline & \multirow[b]{2}{*}{ Model } & \multicolumn{2}{|c|}{ Unstandardized Coefficients } & \multirow{2}{*}{$\begin{array}{c}\begin{array}{c}\text { Standardized } \\
\text { Coefficients }\end{array} \\
\text { Beta }\end{array}$} & \multirow[b]{2}{*}{$t$} & \multirow[b]{2}{*}{ Sig. } \\
\hline & & $\mathrm{B}$ & Std. Error & & & \\
\hline \multirow[t]{2}{*}{1} & (Constant) & .056 & .061 & & 1.825 & .001 \\
\hline & Organizational Learning & .643 & .026 & .588 & 3.166 & .000 \\
\hline
\end{tabular}

a. Dependent variable: Marketing capabilities (Y1). Source: Processed data by author's 
The results in Table 4 show the results of the standard beta coefficient of 0.588 , which means that the organizational learning variable has a significant and positive effect on increasing customer satisfaction by $58.8 \%$. Based on the results show that $\mathrm{H}_{2}$ from t-table $0.6757<$ from t-count 3.166 with a significant $0.00 \leq 0.05$, which means that hypothesis 2 significantly increases customer satisfaction. This can be used as a reference for body shop product companies to always carry out organizational learning in increasing customer satisfaction.

\section{4 t-statistic test (marketing capabilities and organizational learning improve marketing capabilities)}

The $t$ test in the next model is hypothesis 3 and hypothesis 4 , so to draw conclusions for each variable, a direct effect test is carried out. The purpose of this test is that the results can be used as a reference for the body shop product companies, how much influence and importance exogenous variables affect endogenous variables.

Table 5

Partial output linear regression

\begin{tabular}{|c|c|c|c|c|c|c|}
\hline & \multirow[b]{2}{*}{ Model } & \multicolumn{2}{|c|}{ Unstandardized Coefficients } & \multirow{2}{*}{$\begin{array}{c}\begin{array}{c}\text { Standardized } \\
\text { Coefficients }\end{array} \\
\text { Beta } \\
\end{array}$} & \multirow[b]{2}{*}{$\mathrm{t}$} & \multirow[b]{2}{*}{ Sig. } \\
\hline & & $\mathrm{B}$ & Std. Error & & & \\
\hline \multirow[t]{3}{*}{1} & (Constant) & .015 & .021 & & 1.130 & .003 \\
\hline & Marketing Capabilities & .436 & .032 & .402 & 2.243 & .000 \\
\hline & Organizational Learning & .342 & .062 & .316 & 2.715 & .001 \\
\hline
\end{tabular}

Based on the results show that hypothesis 3 and hypothesis 4 have the same line of influence on endogenous, namely customer satisfaction. Table 5 shows the results of the $\mathrm{H} 3$ for organizational learning variables from the t-test of $2.715 \geq$ 0.6757 and a significance of $0.001 \leq 0.05$, which means that it is significant positive. From the next results, the number on standardized coefficients beta is 0.316 , meaning that the effect of organizational learning is $31.6 \%$ to increase customer satisfaction. This proves that the higher organizational learning, the better it is in increasing consumer satisfaction in the body shop products. Furthermore, hypothesis testing 4 shows that the results in table 5 prove that the t-test results are 2.243 $\geq 0.6757$ and a significance of $0.00 \leq 0.05$, which means that the marketing capabilities variable has a positive significance towards the endogenous customer satisfaction variable. At H4, the standardized coefficients beta value is 0.402 , which means that marketing capabilities significantly increase customer satisfaction by $40.2 \%$. In this study also carried out the $\mathrm{f}$ test, which is meant for the ANOVA test model, how is the effect of the independent variable test on the dependent variable.

\subsection{F test (ANOVA)}

In this study, the f-test was carried out to determine whether the variables of entrepreneurial orientation, organizational learning, marketing capabilities have a direct effect to increase customer satisfaction. In the regression model test, the f test is also known as the ANOVA test which looks at the comparison of the results from the f-table test and the f-count test, with a description that if the f-table is smaller than the f-count, the results have an influence in increasing the costumer satisfaction variable (Altinay et al., 2019). For that it is very important to do this ANOVA test, along with the reviews.

Tabel 6

Multiple output regression f-test

\begin{tabular}{ccccccc}
\hline & Model & Sum of Squares & df & Mean Square & F & Sig. \\
\hline \multirow{2}{*}{1} & Regression & 117.032 & 2 & 26.156 & 39.892 & $.000^{\mathrm{b}}$ \\
& Residual & 44.715 & 198 & .136 & & \\
\cline { 2 - 7 } & Total & 161.747 & 200 & & & \\
\hline
\end{tabular}

a. Dependent variable: Marketing Capabilities, Customer Satisfaction

b. Predictors: (Constant), Entrepreneurial Orientation, Organizational Learning. Source: Processed data by author's

According to Table 6 , the f-count is $39.892 \geq 3.89$ (f-table) and the significance is $0.00 \leq 0.05$, which indicates that there is a linear relationship between independent variables of entrepreneurial orientation (X1) and organizational learning (X2) encouraging marketing capabilities (Y1) on customer satisfaction (Y2). The results of this study when viewed in a model using mediation to confirm the results, testing with SEM-AMOS aims to see the value of the loading factor to answer the relationship in the model with multidimensional mediation in a complicated relationship (Arbuckle, 2016). The results of the analysis presented in Fig. 3 below are the second step of quantitative testing and the results are that exogenous variables have a positive and significant effect on endogenous variables directly, and exogenous variables can lead to significant positive mediation towards endogenous variables.

Fig. 3 explains that both in the analysis of the SPSS program and the SEM-AMOS 23.0 program, this study is confirmed from the SEM-AMOS analysis that the relationship between the direction of the line of influence is very important in business organizations to achieve business goals based on consumer needs in reaching consumers. This states that marketing capability is a full mediation (complete mediation), which is an important variable and has an indispensable role in increasing consumer satisfaction (Kristinae et al., 2020). That is, customers who need a sales service system, friendly prices 
/ price compatibility in product quality to get satisfaction. So that business units need a supply chain management system that is relevant, potential in the business management process to get customer satisfaction for body shop products in Central Kalimantan Province and in South Kalimantan Province.

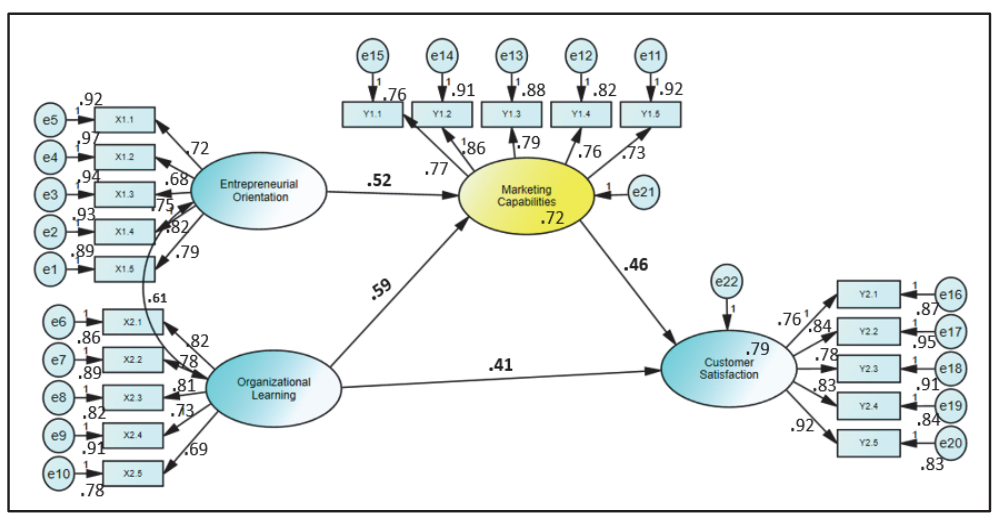

Fig. 3. Results of analysis with SEM-AMOS23.0 (data source analyze by authors)

\subsection{Hypothesis testing}

This study from the model has one mediating variable analyzed to get results that can be interpreted and used as a reference for the results of the hypothesis, then the test is continued with SEM-AMOS 23.0 (Kristinae et al., 2020; Christa \& Kristinae, 2020; Arbuckle, 2016). SEM-AMOS testing has the advantage of being able to confirm the goodness of complicated models and the purpose of doing it with this SEM-AMOS analysis tool to strengthen the SPSS results, and the results taken are critical ratios, standard estimates and probability to see the effect of exogenous variables on endogenous variables stated in Fig. 3 and in Table 7. The results show that the four hypotheses have a significant positive effect and are important variables in increasing customer satisfaction.

Table 7

Hypothesis Results

\begin{tabular}{|c|c|c|c|c|c|c|}
\hline Hypothesis & Std. Estimation & Estimate & S.E. & CR(1.96) & $\mathrm{P}(0.05)$ & Results \\
\hline $\mathrm{MC} \leftarrow$ Entrepreneurial Orientation & 0.621 & 0.971 & 0.052 & 17.731 & $* * *$ & Accepted \\
\hline $\mathrm{MC} \leftarrow$ Organizational Learning & 0.711 & 0.993 & 0.059 & 19.764 & 0.0 & Accepted \\
\hline $\mathrm{CS} \leftarrow$ Marketing Capabilities & 0.523 & 0.852 & 0.046 & 15.886 & 0.91 & Accepted \\
\hline $\mathrm{CS} \leftarrow$ Organizational Learning & 0.317 & 0.812 & 0.041 & 13.208 & 0.93 & Accepted \\
\hline & & & \multicolumn{2}{|c|}{ Chi-Square } & 16.153(ok) & \\
\hline The goodness of fit of the model & & & \multicolumn{2}{|c|}{ Significant } & $0.516 \geq 0.5(\mathrm{ok})$ & \\
\hline
\end{tabular}

Sources: data analyze by authors

The results of this study indicate that the research of Qureshi et al. (2017) cannot be accepted, which means that this study states that the X1 variable (entrepreneurial orientation) can significantly positively encourage the marketing capabilities of the body shop products in Central Kalimantan and South Kalimantan based on the factor loading value. $51 \%$, cr is 18,731 and a probability $* * *$ (smaller than 0.0001 ). Furthermore, the variable X2 (organizational learning) in encouraging marketing capabilities results in $\mathrm{H} 2$ from the results of a factor loading value of 59\%, c.r 19,764 and a probability of 0.00 so that the OL variable is very important in pushing the marketing system to the marketing capabilities variable. Next, H3 shows the factor loading value of $46 \%$, the result of c.r 13,208 and a probability of 0.03 , which means that the hypothesis is accepted and the OL variable plays an important role in increasing customer satisfaction. Finally, H4 is based on a factor loading value of $41 \%$, the result of c.r is 15,886 and a probability of 0.01 , which means that the hypothesis is accepted and marketing capabilities have an important role in increasing customer satisfaction. Based on the research results, the proposed hypothesis is accepted and the research model is also good from the goodness of fit model, namely the chi square 16,153 (in statistical terms it is expected to be small) and the significance is 0.51 greater than 0.5 . The variables in the research through the indicator parameters, the results of the analysis are very good with entrepreneurial orientation and always carry out organizational learning to encourage marketing capabilities to increase consumer satisfaction during the COVID-19 pandemic (Kristinae, 2019). For business actors / body shop product companies in the province of Central Kalimantan and in the province of South Kalimantan, the results can be a reference and basis for continuing to make changes and improvements to the management system in the business with the SCM business strategy pattern and the application of the $\mathrm{RBV}$ theory in management management to support business sustainable by increasing customer satisfaction.

\section{Conclusion}

Companies engaged in products must be able to maintain a management strategy with a business pattern that meets consumer satisfaction (Müller et al., 2018). The resource view theory provides methods that companies can apply to empower resources in resource institutions effectively and efficiently, also proving that marketing capabilities are 
significant with the encouragement of entrepreneurial orientation (Kristinae et al., 2020), the results show the rejection of the gap in previous empirical studies (Qureshi et al., 2017). Several methods include implementing an entrepreneurial orientation proactively, innovatively and taking risks to obtain information and knowledge that currently exists, as well as being applied to encourage marketing capabilities to be able to provide a marketing system that is easy, fast and does not trust consumers so that customer satisfaction is achieved (Arzubiaga et al., 2018). Several empirical studies suggest that EO significantly increases CS. This research illustrates that through mediation marketing capabilities is a new research with excellent results in increasing customer satisfaction. The results of body shop research which has the motto "good things inside" are very good at increasing consumer satisfaction through entrepreneurial orientation, organizational learning and mediation marketing capabilities in Central Kalimantan and in South Kalimantan, Indonesia. Organizational learning in product companies can be a reference for increasing consumer satisfaction with the SCM pattern, starting with quality product raw materials, product availability, product variants, product benefits in meeting consumer satisfaction (Andrews, 2017). Likewise, OL in encouraging mediation marketing capabilities makes the company continue to learn in management and learning to gain knowledge, get information in making changes to sales methods, new product information, transaction information so that consumers can easily get products and feel comfortable transactions, which can create satisfaction. consumers (Andreou et al., 2016). The ultimate goal of this research is to create customer satisfaction to manage management more structured and get consumers who have loyalty to the product, so that the business of The Body Shop in Central Kalimantan and in South Kalimantan, continues to run well even though the business environment is experiencing turbulence. This research was conducted on the business of environmentally friendly product companies that are well known to the public in the Kalimantan region, so that it is not necessarily applicable to other product research which is a limitation of the research. In enriching research in the field of management with the SCM pattern, further research can be carried out by adding variables such as social capital, green market orientation, technology orientation and business performance.

\section{Acknowledgments}

We would like to thank the people for their cooperation of the agency's product outlet companies in Central Kalimantan and South Kalimantan provinces in Indonesia.

\section{References}

Ab Talib, M. S., Abdul Hamid, A. B., \& Thoo, A. C. (2015). Critical success factors of supply chain management: a literature survey and Pareto analysis. EuroMed Journal of Business, 10(2), 234-263.

Abdirad, M., \& Krishnan, K. (2020). Industry 4.0 in logistics and supply chain management: A systematic literature review. Engineering Management Journal, 1-15.

Abu Seman, N. A., Govindan, K., Mardani, A., Zakuan, N., Mat Saman, M. Z., Hooker, R. E., \& Ozkul, S. (2019). The mediating effect of green innovation on the relationship between green supply chain management and environmental performance. Journal of Cleaner Production, 229, 115-127. doi:10.1016/j.jclepro.2019.03.211

Adam, M., Ibrahim, M., Ikramuddin, I., \& Syahputra, H. (2020). The Role of Digital Marketing Platforms on Supply Chain Management for Customer Satisfaction and Loyalty in Small and Medium Enterprises (SMEs) at Indonesia. International Journal of Supply Chain Management, 9(3), 1210-1220.

Agarwal, S. (2019). Deep Learning-based Sentiment Analysis: Establishing Customer Dimension as the Lifeblood of Business Management. Global Business Review, 0972150919845160.

Al-Aomar, R., \& Hussain, M. (2018). An assessment of adopting lean techniques in the construct of hotel supply chain. Tourism Management, 69, 553-565. doi:10.1016/j.tourman.2018.06.030

Al-Dhaafri, H. S., Al-Swidi, A. K., \& Yusoff, R. Z. B. (2016). The mediating role of total quality management between the entrepreneurial orientation and the organizational performance. The TQM Journal, 28(1), 89-111.

Al-Hazmi, N. M. (2020). The impact of information technology on the design of distribution channels. Uncertain Supply Chain Management, 505-512. doi:10.5267/j.uscm.2020.4.002

Altinay, L., Song, H., Madanoglu, M., \& Wang, X. L. (2019). The influence of customer-to-customer interactions on elderly consumers' satisfaction and social well-being. International Journal of Hospitality Management, 78, 223-233.

Andreou, P. C., Louca, C., \& Petrou, A. P. (2016). Organizational learning and corporate diversification performance. Journal of Business Research, 69(9), 3270-3284. doi:10.1016/j.jbusres.2016.02.022

Andrews, M. (2017). Turbulent and Dynamic Times: The Importance of Tacit Knowledge and Organizational Learning in a Young E-Commerce Company. Journal of Organizational Psychology, 17(5), 37-51.

Antunes, H. D. J. G., \& Pinheiro, P. G. (2020). Linking knowledge management, organizational learning and memory. Journal of Innovation \& Knowledge, 5(2), 140-149.

Anonymous. (2016). Ideas, experiments and open minds: Learning is not just about correcting mistakes. Development and Learning in Organizations: An International Journal, 30(4), 27-29.

Aparicio, G., Basco, R., Iturralde, T., \& Maseda, A. (2017). An exploratory study of firm goals in the context of family firms: An institutional logics perspective. Journal of Family Business Strategy, 8(3), 157-169.

Akinci, C., \& Sadler-Smith, E. (2019). Collective intuition: Implications for improved decision making and organizational learning. British Journal of Management, 30(3), 558-577.

Arbuckle, J. L. (2016). IBM® SPSS® Amos ${ }^{\mathrm{TM}}$ User's Guide. 
Arzubiaga, U., Kotlar, J., De Massis, A., Maseda, A., \& Iturralde, T. (2018). Entrepreneurial orientation and innovation in family SMEs: Unveiling the (actual) impact of the Board of Directors. Journal of Business Venturing, 33(4), $455-469$.

Barney, J. (2001). The resource-based view of the firm: Ten years after 1991. Journal of Management, 27(6), 625-641.

Basari, M. A. M. D., \& Shamsudin, M. F. (2020). Does Customer Satisfaction Matters?. Journal of Undergraduate Social Science and Technology, 2(1).

Berghman, L., Matthyssens, P., \& Vandenbempt, K. (2012). Value innovation, deliberate learning mechanisms and information from supply chain partners. Industrial Marketing Management, 41(1), 27-39.

Cacciolatti, L., \& Lee, S. H. (2016). Revisiting the relationship between marketing capabilities and firm performance: The moderating role of market orientation, marketing strategy and organisational power. Journal of Business Research.

Cenamor, J., Parida, V., \& Wincent, J. (2019). How entrepreneurial SMEs compete through digital platforms: The roles of digital platform capability, network capability and ambidexterity. Journal of Business Research, 100, 196-206.

Christa, U. R., \& Kristinae, V. (2020). The effect of product innovation on business performance during COVID 19 pandemic. Uncertain Supply Chain Management, 9. doi:10.5267/j.uscm.2020.10.006

Christa, U. R., Wardana, I. M., Dwiatmadja, C., \& Kristinae, V. (2020). The Role of Value Innovation Capabilities in the Influence of Market Orientation and Social Capital to Improving the Performance of Central Kalimantan Bank in Indonesia. Journal of Open Innovation: Technology, Market, and Complexity, 6(4). doi:10.3390/joitmc6040140

Cuevas-Vargas, H., Parga-Montoya, N., \& Fernández-Escobedo, R. (2019). Effects of entrepreneurial orientation on business performance: The mediating role of customer satisfaction-A formative-Reflective model analysis. $S A G E$ Open, 9(2), 2158244019859088.

El-Adly, M. I., \& Eid, R. (2016). An empirical study of the relationship between shopping environment, customer perceived value, satisfaction, and loyalty in the UAE malls context. Journal of Retailing and Consumer Services, 31, $217-227$.

Farzaneh, M., Ghasemzadeh, P., Nazari, J. A., \& Mehralian, G. (2020). Contributory role of dynamic capabilities in the relationship between organizational learning and innovation performance. European Journal of Innovation Management.

Hong, Z., \& Guo, X. (2019). Green product supply chain contracts considering environmental responsibilities. Omega, 83, $155-166$

Khaddam, A. A., Irtaimeh, H. J., \& Bader, B. S. (2020). The effect of supply chain management on competitive advantage: The mediating role of information technology. Uncertain Supply Chain Management, 8(3), 547-562.

Kristinae, V., Sambung, R., \& Sahay, M. (2019). The Role Of Entrepreneurial Orientation In Product Innovation In Emerging Markets On The Local Products. Oradea Journal of Business and Economics, 4(2), 35-44.

Kristinae, V. W., IM.Giantari,IGK.,Rahyuda.AG,. (2020). The role of powerful business strategy on value innovation capabilities to improve marketing performance during the COVID-19 pandemic. Uncertain Supply Chain Management, $8(45), 675-684$.

Kuo, H. C., \& Nakhata, C. (2019). The impact of electronic word-of-mouth on customer satisfaction. Journal of Marketing Theory and Practice, 27(3), 331-348.

Migdadi, M. M. (2019). Organizational learning capability, innovation and organizational performance. European Journal of Innovation Management.

Müller, J. M., Pommeranz, B., Weisser, J., \& Voigt, K.-I. (2018). Digital, Social Media, and Mobile Marketing in industrial buying: Still in need of customer segmentation? Empirical evidence from Poland and Germany. Industrial Marketing Management, 73, 70-83.

Nahan, N.,V., Kristinae, \& Leiden, R,A,Z. (2019). The strength of a business strategy with value innovation for Rattan Handicraft Entrepreneurs in central Kalimantan, Indonesia. The International Journal of Business \& Management, $7(12)$.

Shahzadi, M., Malik, S. A., Ahmad, M., \& Shabbir, A. (2018). Perceptions of fine dining restaurants in Pakistan: What influences customer satisfaction and behavioral intentions? International Journal of Quality \& Reliability Management, $35(3), 635-655$.

Soltani, S., Ramazanpoor, E., \& Eslamian, S. (2014). A Structural Equation Model of the Impact of New Product Development on Competitive Advantage. Engineering Management Research, 3(1), 99-108.

Sudari, S., Tarofder, A., Khatibi, A., \& Tham, J. (2019). Measuring the critical effect of marketing mix on customer loyalty through customer satisfaction in food and beverage products. Management Science Letters, 9(9), 1385-1396.

Qureshi, M. S., Aziz, N., \& Mian, S. A. (2017). How marketing capabilities shape entrepreneurial firm's performance? Evidence from new technology based firms in turkey. Journal of Global Entrepreneurship Research, 7(1), 15.

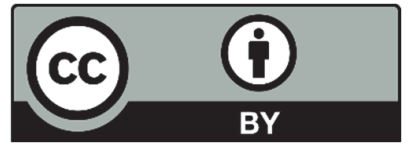

(C) 2021 by the authors; licensee Growing Science, Canada. This is an open access article distributed under the terms and conditions of the Creative Commons Attribution (CC-BY) license (http://creativecommons.org/licenses/by/4.0/). 